\title{
The Pentecostal Antirevolution: Reflections from Angola
}

\author{
Ruy Llera Blanes | ORCID: 0000-0001-7547-8920 \\ School of Global Studies, University of Gothenburg, Gothenburg, Sweden \\ ruy.blanes@gu.se
}

Natalia Zawiejska | ORCID: 0000-0002-4298-1324

Jagiellonian University, Krakow, Poland

natalia.zawiejska@uj.edu.pl

\begin{abstract}
This article discusses the so-called 'revolutionary' character of Evangelical and Pentecostal movements, as has been proposed in mainstream sociological and anthropological literature. Through a historical and ethnographic account of Evangelical and Pentecostal Christianity in Angola, we suggest that in this country Evangelicalism and Pentecostalism is defined by exclusionary tactics that render most churches compliant with the current political regime, and they in fact act as reactionary, conservative forces in contexts of social and political disruption. This in turn exposes a divergence in terms of political rhetoric and praxis among Evangelical and Pentecostal movements.
\end{abstract}

\section{Keywords}

Angola - Evangelicalism - Pentecostalism - politics - revolution

\section{Introduction: Debating Pentecostalism and Revolution}

The mainstream literature that emerged in the latter part of the twentieth century on Evangelical and Pentecostal movements ${ }^{1}$ has traditionally highlighted their revolutionary character (Martin 1996), stressing the oftendramatic societal ruptures provoked by their implantation and success in places like Latin America, Africa, and Asia. This affects not only the individual 
lives of adherents and believers, but also wider social instances and identity configurations through a 'politics of conviction' (Comaroff 2009) more often than not based on ideologies of spiritual warfare and religious militancy. For instance, David Martin's sociological take on the emergence of Evangelicalism and Pentecostalism frames it as nothing short of an 'explosion' (1990), paving the way for a progressive understanding of such movements as inherently revolutionary or at least 'rupturist' in their political, ideological, and societal stances (Cox 1995; Chesnut 1997; Meyer 1998; Harding 2000; Marshall 2009; O'Neill 2010; Martin 2014; Morier-Genoud 2014). Such literature was important in revealing a new political ethos in Christian experience that differs from the more classical political theology that framed Western political philosophy from a Christian framework (Agamben 2012).

In what terms do these tropes of rupture, explosion, and transformation couple with the idea of revolution? One early discussion in this respect is Birgit Meyer's now-classic argument on Pentecostalism's 'complete break with the past' (1998), which illustrates the urge to combat tradition (and subsequently demonic practices) in the burgeoning Pentecostal movements in 199os Ghana. As Meyer explains, this rupturing reflected a temporal orientation (evil past versus triumphant future) that was central to local pastors' ideologies. Here the oppositionist stance of spiritual warfare between the Holy Spirit and evil traditional spirits is central, often translating into the formation of believers as militants and ultimately militarizing tropes such as the 'end-time army' (Ojo 2007).

However, as Nigerian Pastor Ojewale, cited in the opening of Ruth Marshall's book Political Spiritualities. The Pentecostal Revolution in Nigeria (2009), reminds us, the revolution of the Pentecostals is actually a bloodless one, one that translates into the conquest and reclamation of the everyday for believers. What Marshall subsequently describes in her analysis of the Pentecostal landscape of Nigeria is a Pentecostalism that addresses both subjective and collective epistemological and ontological insecurities in urban postcolonial Nigeria, and is ultimately an individual self-transformative project.

In reaction, following recent similar interrogations (Morier-Genoud 2014), we seek to further push the debate: how does this rupture/revolution actually translate into political activity, specifically in what concerns participation in the public and partisan sphere? To what extent and in what terms is the revolutionary rhetoric actually engaging in the transformation of governance and citizenship? Anthropological accounts from Latin America have highlighted this process in great detail. For instance, Kevin O'Neill's analysis of Evangelical politics in Guatemala (2010) exposes how the trope of revolution was embedded within Neopentecostal advocacy toward citizen and political participation. 
Similarly, in Brazil we are all aware of how Pentecostal denominations have developed strategies to enable a bancada evangélica (Evangelical representation and lobbying) in the Brazilian parliament (Prandi and Dos Santos 2017).

From this point of view, the African continent is an interesting case in point, considering the political histories - from colony to independence - that it harbours. On the one hand, as Paul Freston duly noted, many of the independentist/liberationist political movements and protagonists in the continent were inspired by a missionary Protestant upbringing (2001), which eventually enabled an antihegemonic and antihierarchical consciousness among many Africans who later became active in anticolonial struggle. This was certainly the case in Angola, where two of the main leaders of the independence process, Agostinho Neto and Jonas Savimbi, were sons of Protestant ministers (Blanes and Paxe 2015). Many African Independent Churches, as they used to be called, would later use more or less radical emancipatory rhetoric in order to promote divergent, antihegemonic understandings of the role of Christianity in Africa (Comaroff and Comaroff 1991; Sanneh and Carpenter 2005; Lindhardt 2015). However, if this new epistemology was initially framed against an external agent (e.g., European colonialism, northern, Western, or white missions in Africa), later studies unveiled how, in the postcolonial period, new modalities of Evangelicalism and Pentecostalism addressed internal, individualizing aspects of African society. This was the case, for instance, with Birgit Meyer (1998) and Ruth Marshall (2009), who put forward groundbreaking accounts of the social and political agency of these movements in such countries as Ghana and Nigeria, namely in terms of addressing traditionalism and its role in African life.

On the other hand, as Adrian Hastings (1995) and Terence Ranger (2008) discuss, early Protestant, Evangelical, and Pentecostal missionaries in late colonial Africa typically remained voluntarily marginal during, and self-excluded from, the decolonization period in Africa, withdrawing from the public sphere during the height of the struggles for independence (see also Burgess 2015). In fact, more often than not they positioned themselves alongside the colonial project and against emergent autochthon movements. For instance, this was certainly the case of the Baptist Missionary Movement in northern Angola and the DR Congo, where Belgian missionaries eagerly denounced local emergent religious movements as anticolonial conspiracies (see MacGaffey 1983 and Covington-Ward 2016 regarding the Kimbanguist movement in the 1920s; and Blanes 2014 regarding the case of the Tokoist Church in the late 1940s) This was also the case with the missionary project of the Assemblies of God in Angola, who were at first in conflict with the colonial authorities taking on a marginal and withdrawn attitude in relation to public sphere activities. Yet at the end 
of colonial era the authorities of this religious group were eager to cooperate with colonial powers in return for noninterference in the internal issues of the group (Martins 2004).

This is a first acknowledgement of the main argument in this paper, which works in response to recent debates regarding Pentecostalism as a very public affair in contemporary Africa (Gifford 1998; Englund 2007; McCauley 2015). Despite its inherent combative, rupturist, and transformational rhetoric, Evangelical and Pentecostal ideology remains for the most part a fundamentally conservative and antirevolutionary force vis-à-vis the current political landscape in Africa, marked by the widespread celebration of five decades of independence throughout the continent. In other words, in times of political turmoil (i.e., war, authoritarian oppression, political conflict, or resistance), such movements appear more as agents of conservatism than of revolution, in particular through processes of subjectification and self-exclusion from the political partisan sphere. As we argue, this is revelatory of two acknowledgements: that in many contexts, Pentecostalism's revolutionary stance is more than anything an aesthetic symbolic statement geared toward individualizing and internalizing conceptions of transformation; and that it embodies what is fundamentally a conservative mode of political ideology that is ultimately exclusionary and impeditive of political participation and activism of religious practitioners. This is at least what we see in places like Angola, where we observe a current situation of political unrest produced, among other things, by an activist contestation against an otherwise authoritarian and nepotistic regime (Blanes 2015c, 2017).

Further on we describe two ethnographic contexts involving Pentecostal churches in Luanda, which we believe illustrate how problematic the conjunction of Pentecostalism and revolution can be. We suggest that in this country Evangelical and Pentecostal churches stage self-exclusionary tactics that render most of them silently compliant with, when not supportive of, the current authoritarian political regime, and in fact act as reactionary, conservative, status quo forces in situations of social and political disruption. This, we acknowledge, contrasts with other religious landscapes in Africa such as Nigeria, Ghana, Malawi, or Zambia, where we observe an active engagement and interlocution with partisan politics. This is what Ruth Marshall tells us in her description of the empire-building strategies of the Redeemed Christian Church of God in Lagos (2009). On the other hand, Naomi Haynes describes the spiritual landscape that emerges from the fact that Zambia is constitutionally recognized as a 'Christian nation' (2015), which has allowed for an integration of partisan and governmental politics into a covenantal logic while simultaneously transforming Pentecostal believers into active political participants who take part in the 
infrastructural construction of a prosperous nation. However, as she subsequently describes (2018), even within that covenantal space the Pentecostal involvement in partisan politics may not always reverberate into constructive nation-building narratives but instead into logics of suspicion and critique in the space that connects Pentecostalism and politics.

Another noteworthy example of this is that of the Bundu Dia Kongo (BDK) movement in the DR Congo, which also has a following in northern Angola (Sarró 2018). Founded by Ne Muanda Nsemi, it couples a theology of prophecy and charisma with a nationalist emancipatory agenda - the reinstatement of the Kingdom of Kongo - resulting in explicit political persecution from the Congolese authorities (Covington-Ward 2016).

In this framework, our point of departure is that despite the obvious political content of the concept of revolution, the Pentecostal revolution that is often depicted in Africa is located in a conceptual, ideological, and experiential space that is not the concrete sphere of partisan and government politics, a more abstract and rhetorical political place that does not intervene in secular politics, even when it singles it out as an object of critique. We argue that while recognizable from within the rupturist ethos of the conversion narrative, in Pentecostal and Evangelical regimes revolution eventually submerges into more conservative and abstract political stances. In the ethnographic discussion that follows, we illustrate how this comes about. Before doing so, we begin with a characterization of religion and Christianity in post-independence Angola.

\section{Silent Churches: Christianity and Revolution in Angola}

The points made by Hastings and Ranger cited above regarding Evangelical withdrawal from the political landscape in the liberationist period could also be applied to the Angolan case, in particular during the period in which the war for the country's independence was waged (1961-1975; see Schubert 200o). During this period, as Edmundo Rocha notes, if there were any Christian leaderships actively fighting for Angolan independence, they came from the Catholic front, despite their hierarchy's defense of the colonial regime (2003). Furthermore, regardless of the political stances at stake, the Portuguese colonial authorities were more focused on targeting the movements they considered to be more subversive or dangerous: autochthon movements such as the Kimbanguists and the Tokoists, and noncompliant missionary movements such as the Jehovah's Witnesses (Blanes 2014; Blanes and Paxe 2015). One could argue that during the liberation period the concept and instrumentality of revolution was 
subsumed under the victorious narrative of the then Marxist-Leninist MPLA party, which seized power after independence (1975) and has governed ever since, despite the civil war that ensued from then until 2002. In the first years of independence, not only was religion removed from the public sphere, but it was also ontologically framed as a 'zone of abandonment' (Biehl 2014), as it were, a social space excluded from the secular 'New Angola' that was enacted at the time (Schubert 1999; Blanes and Paxe 2015).

However, since the 198 os the public space of Christian churches was progressively reinstated, and a group of elite churches have become active agents in the processes of peace building (Schubert 2000; Viegas 2007; Neves 2012) and democratization in Angola, ${ }^{2}$ establishing themselves as protagonists in the public sphere and addressing several governmental sectors such as social welfare and development in similar terms as observed in other regions of Africa (Gifford 1995, 1998; Freeman 2012). In this framework, in the first rounds of official recognition of religious institutions $(1987,1992)$ only a few dozen churches were recognized (Blanes 2014). After the social, economic, and political reforms that transformed Angola into a social democracy in 1992, the subsequent years witnessed nothing short of an explosion of religious and notably Christian churches dwelling in the urban landscapes of Angola and engaging in processes of institutional and social recognition (Viegas 2007). As of 2010, for instance, there were eighty-three officially recognized religious institutions in Angola, and around 850 awaiting juridical recognition (INAR 2010), making religion at the very least a very public affair in Angola.

In this respect, the public place of the major Pentecostal and Evangelical churches in Angola today cannot be disconnected from the political and partisan reality in the country (Schubert 2017). As argued above, Angola is today a country ruled by an authoritarian, self-perpetuated regime enacted by a de facto single ruling party (the MPLA, despite the multipartisan framework), in which the public space occupied by the main churches is a result not only of a process of cooptation (Blanes 2015b), but also, as recently argued by Didier Péclard, of depoliticization (2013). It is a political process by which hegemonic churches become agents working for the status quo promoted by the regime, providing moral and social legitimation to the government policies under the postwar rhetoric of peace, reconciliation, and reconstruction. It is for this reason that, for instance, we observe the continuous alignment between government-sponsored campaigns regarding such issues as health and education, and the public interventions of church leaders (Blanes 2014), as well as a growing public presence of ecumenical associations in the Angolan landscape sponsored by this state policy of control. Apart from the older Catholic CEAST (Episcopal Conference of Angola and São Tomé), one example is the CIRA 
(Council of Renewal Churches of Angola), which brings together hundreds of churches that have not yet been able to achieve recognition. Another, older example is the CICA (Council of Christian Churches of Angola), which represents the Protestant, Evangelical, and Pentecostal branches that are at the top of the hierarchy in historical, demographic, and financial terms. Founded as the Angolan Council of Evangelical Churches at the height of the antireligious policy in 1977, the CICA acquired public status in 1992 in the framework of the politico-constitutional changes that followed the short-lived peace accord of Bicesse. Today they position themselves as a think tank for the presidential cabinet while acting as spokesmen, channeling the government's social and political agenda. However, they are increasingly seen by those who contest the regime as an example of a corrupt elite, more interested in privilege than in improving the country's situation, in particular considering the recurring cases of persecution and violence against political dissidence in Angola enacted by the very state that the (silent) churches support (Blanes 2015b).

Other, more off-route examples of how this process takes place could be given. The first case is that of the so-called Luz do Mundo (Light of the World) church, also known as Kalupeteka Church, after its founding prophet José Julino Kalupeteka. This church's stronghold is in the Huambo region, historically associated with the regime's main opposition, UNITA (Pearce 2015; Muekalia 2017). It became famous nationwide after violent clashes with the police in 2015 that resulted in several killings and Kalupeteka's arrest. Since its inception in the early 200os, the Luz do Mundo was, like other several hundred churches in Angola, awaiting official recognition from the Angolan government. This particular church is an excision from the Seventh-Day Adventist Church of Angola, after Kalupeteka - a former choir singer and youth leader - decided to leave the church and create his own movement. In 2014 local estimates counted close to 4,00o followers of the Luz do Mundo, which proclaimed a millennial belief in the second coming of Christ. ${ }^{3}$ In late 2013 the Ministry of Justice issued a statement that overruled the application of several dozen churches awaiting recognition, among them the Luz do Mundo. This created a situation in which, throughout 2014, the church had several encounters with the local authorities, who continuously attempted to close down the church. The church resisted, and eventually José Julino Kalupeteka began summoning his followers to 'leave everything behind' and follow him to a hill near the city of Huambo, Monte Sumi, to await the 'voyage to heaven' (Orre 2015). According to local reports, several thousand believers from nearby villages followed him to the mountain to create what José Eduardo Agualusa, the famous Angolan fiction writer, aptly described as an 'Angolan Canudos' (Rede Angola, 26/04/2015). This was a reference to the late nineteenth-century 
Brazilian village created by Antonio Conselheiro, a self-governed, independent spiritual community that withdrew from worldly power and was subsequently destroyed by state forces.

In late April the local police staged an invasion to shut down the Mount Sumi camp. As a result, nine police officers were killed and several injured. In an immediate response, special army (FAA) forces entered the camp and allegedly murdered thousands of followers with several hours of continuous gunfire. Some followers responded by attacking officers with stones, pieces of wood, and catanas (long knives). To date, two thousand followers are listed as missing. Kalupeteka was arrested, tortured, and almost beaten to death. He was accused of the murder of the nine policemen and condemned to 28 years of jail - more than the current Angolan penal framework actually allows. Subsequent statements from the government omitted the description of the actual events, and presented the police intervention as a liberation of thousands of citizens' (Angola Press, 20 April 2015). Their statements focused on two main narratives: (1) the Light of the World movement was steered by 'other forces' that threatened national security (a rumor circulated that Kalupeteka held a bunker in Mount Sumi filled with war arsenal); and (2) the army intervened in self-defense for the maintenance of public order (Presidential Speech, 20 April 2015).

The second example comes from the IURD church (Universal Church of the Kingdom of God, henceforth UCKG ). This church arrived in Angola in the early 199os, and soon established a strong, visible presence through what has been described as their 'cathedral politics' (Mafra 2003). Their flamboyant Catedrais da Fé (Cathedrals of Faith) in focal points around the city such as the Alvalade neighborhood made a strong impact, and their public image, unlike what occurred in countries such as Portugal (Mafra 2002), was soon established as a positive one, determined by a collaborative relationship with the Ministry of Internal Affairs (Fernando 2010; Blanes 2015c). For instance, the local UCKG leadership took an active role in the government-promoted electoral census campaign of 2006, using their churches as registration centers. Furthermore, as Mafra, Swatowiski, and Sampaio (2012) point out, the UCKG's development of a social welfare strategy in Angola granted them a strong, favorable position in institutional terms. Their expansion throughout the territory was thus fast and successful. They were able to combine a strong transnational circulation between Brazil, Africa, and Europe, of pastors, media, and ideologies with their establishment in the local scene through their investment in constructing churches in practically every neighborhood of Luanda, for instance.

On New Year's Eve of 2013, the UCKG organized a multitudinous event called Os Dias do Fim (The Days of the End) in the national Cidadela stadium in 
central eastern Luanda. The event was intended to counterbalance the traditional Angolan custom of intense celebration of the New Year, usually involving the ingestion of significant amounts of alcohol. A strong marketing and publicity campaign was spread throughout the city, and hundreds of thousands of people showed up at the stadium. The overbooking was such that in a sudden stampede several dozen believers lost their lives. After these events the government's immediate decision was to close down all church activities for 60 days and command the Ministry of Justice to open an investigation. In the meantime, the believers were confined to praying at home, and the multiple UCKG church buildings in Luanda had their front doors locked. However, unlike what happened with another Neo-Pentecostal church closed by governmental decree a few years earlier (the Maná Church, see Blanes 2015a, 2015b), the UCKG quickly reopened and resumed its regular activities. ${ }^{4}$

These cases illustrate two very different examples of church and state relationships in Angola, in particular concerning the Evangelical and (Neo-) Pentecostal sphere. They also exemplify two distinct strategies of political practice and consequences. The Kalupeteka movement became political through a process of self-exclusion with tragic consequences (silenced by the government), the IURD, while remaining below the radar in terms of the public discourse in the Angolan political landscape, reveals a multilayered presence in the manufacture of politics in the country (Schubert 2017) through their strategic collaborations with the state. This in turn implied a process of conformation and withdrawal from the political debate, in particular the critique of regime governance. Through their public silence, they supported the status quo.

These cases also illustrate the conundrum in the current debates concerning Pentecostalism and politics in Africa and elsewhere: Pentecostals seem to be at the same time apolitical and very political (Haynes 2015), begging a clarification of what 'being political' actually means in each context. In the pages that follow we explore two very concrete examples that explain how this process played out in Angola, and illustrate how such layers produce not so much a revolutionary but instead a reactionary form of Christian politics.

In 2014 Zawiejska conducted research on two evangelical Pentecostal churches in Luanda, the Angolan Assembly of God and the so-called Bom Deus church. ${ }^{5}$ Both churches began as local movements but had started to expand and grow rapidly in their visibility in Luanda's public sphere throughout the previous 
decade. Their leaders, although starting from very different social and religious backgrounds (Zawiejska 2016, 2017, 2020; Zawiejska and van de Kamp 2018), managed to include their churches in the established evangelical circuit in Angola and place them as important players in Luanda's public sphere. In the case of the Assembly of God (AG) of Angola, ${ }^{6}$ but particularly in the AG of Maculusso, many members work in the public service sector and administration and are thus middle class. The headquarter of AG of Maculusso is strategically located in one of the central, middle- to upper-class neighborhoods in Luanda. Considering this socioeconomic background, the discourses and narratives usually heard in the AG Maculusso frequently appropriate the state discourses on the country's development, modernization, and Angolan 'new beginning' that are managed by the ruling party (Schubert 2015, 2016, 2017). This discourse frames the church and its adherents as modern (conscious, active, successful, and educated) Christians, in sync with the political movements resonating in the country.

Similarly, in the second case of the Bom Deus church, it is common to see local political leaders and representatives included and encouraged to participate in church services. They are routinely invited to take part in the most significant church events such as the healing campaigns, organized with frequency in different spaces in Angola's capital and throughout different provinces of the country. By engaging in different practices, both churches can be understood to recognize political authority as an important component of the religious lives of their believer-members. However, while molding the subjectivities of their members in respect to political engagement and citizenship duties, these churches also place limits on particular understandings of political performance.

For instance, on 4 February 2014 Zawiejska participated in a women's retreat of the AG Maculusso in Luanda. In AG Maculusso, as in many other Angolan AGs, women form associations within the church structure that become the core of church social and religious life. Through the retreats they cultivate the AG woman as virtuous (mulher virtuosa) and full of Pentecostal fire (mulher fogo), focusing on women's profound religiosity and piety that in turn is considered a crucial element in the church's life.

The meeting took place in the one of small parishes of AG Maculusso (Centro Mensageiro da Fé, Congregação Tanque de Siloe) located in the outskirts of Luanda not far from the national '11th of November' football stadium. The hosting parish provided a very unusual space. Although most of the city musseques (shantytowns) are rather dense and dry with limited green areas, the retreat space was an ample courtyard with several trees. The chosen date was significant and was intended to determine the context of the meeting since 
the day is considered as a commemoration of the beginning of the Angolan liberation struggle against Portuguese colonial domination (Blanes 2015c; Schubert 2017). The date of the prayer meeting was a national holiday, which was intended to facilitate the participation of all women in the 'Maculusso Family', as the church members call the network of all AG Maculusso parishes. Women from different classes, professions, and social spaces were encouraged to connect and unite their prayers on this occasion. The meeting was exclusively for women, although one man, a member of AG Maculusso ministry, assisted with the organization. Women, deaconesses and intercessors, set up and led the entire meeting.

In the early morning, women living in different and sometimes remote quarters of Luanda started to appear at the meeting point in the church headquarters in central Luanda. Dressed mainly in traditional garb, with kerchiefs and panos, the name given in Angola to the African print textiles. For many of them this outfit was unusual in comparison to their quotidian working clothes. Special clothing served as a prelude and sign of the spiritual component of the meeting. During the move from the city center to the retreat space, made in several rented candongueiros (collective taxis), the women began to praise God, as is usual in the introductory moments of every common service in the Angolan AG. When the women reached the space the proper part of the meeting began. It was called and framed by the women as 'nosso trabalho' (our work).

The opening reading of the meeting was significant because the leader had chosen an excerpt from the Book of Chronicles $2(7: 11-16)$ that refers to the importance of submission to God's will and focusing on the power of prayer. The text also considers the role of the political leader and the importance of his obedience to God's rules in shaping the nation's destiny. The reading contained God's promise to heal and rebuild the country as long as its inhabitants remained loyal and pious to him. While the excerpt was being read, particularly verse 14, a wave of enthusiasm was triggered among the gathered women. After the introductory reading, the women gathered in a wide circle and began to pray collectively and individually, with long interludes of praise. They summoned Jesus to guard and protect them, their families, and the church. The climax of the meeting was a prayer for Angola that resonated with the introductory readings. At this point the male assistant began to play an active role in the meeting. He stepped into the circle and, together with women leaders, began summoning and interceding. Thus the prayer 'for our Angola' (clamor por nossa Angola) included all gathered members, marking its weight within the entire meeting. The invocations directed to God focused on granting wisdom to the country's leaders. The leaders of the session emphasized that those 
present deliberately did not address their afflictions to the leaders but delivered them directly to God since only he was capable of acting, introducing change, and performing miracles on the country. Those gathered claimed that each one present at the meeting and each particular individual in general was a part of society. At the same time, he or she is also a part of the body of God (corpo de Deus), and therefore individual and group prayers have legitimate power to change the nation's destiny.

During the prayer for Angola, a huge toad suddenly entered the circle and stopped right the middle. The gathered women acted quickly and without any hesitation: they grabbed sticks and stones and passionately killed the creature it. Zawiejska later interrogated some of the women about the incident. They claimed the toad may have been an incorporated demon that entered the praying circle to hinder, interrupt, and destroy the meeting and invalidate the prayers. It could have brought misfortune to the country and its population. ${ }^{7}$ The women viewed getting rid of the toad in spiritual terms, as was the whole meeting that was intended to fulfill the commitment and obligations every citizen has in respect to the nation and the state.

Although the case of Bom Deus differs from the example given above, it is similar in respect to understanding the political engagement of the church, captured as the spiritual unity of different subjectivities. The Bom Deus church focuses on divine healing. The services frequently take place outside the church buildings and engage masses that circulate in certain spaces of the city. This practice resembles the healing campaigns organized by American missionaries, in particular Tommy Lee Osborn. Osborn served as an inspiration for the leader of Congolese church Nzambe Malamu, from which Bom Deus had separated in the 199os (Fischer 2011; Zawiejska 2017; Zawiejska and van de Kamp 2018). During campaigns organized by the Bom Deus church, people seeking spiritual and physical healing gather for day-long praying sessions. These sessions culminate with healing prayer after which a few hundred people witness the divine cleansing and healing that had just occurred in their bodies and spirits. They let go of their crutches or point to healed body parts, and also refer to the spiritual change they feel. During the service a special area, close to the pulpit and next to the gathered service attendees, is organized for important guests, visitors, high-ranking church ministers, and representatives of the local administration or government fellows. This close presence of political authorities does not resonate with the religious performance and narratives during readings, praying sessions, or sermons. These concentrate on such different aspects as shaping one's own spiritual mastery, God's potency, and molding social comportment according to Christian ethics. 
However, the Bom Deus church may serve as an example of what we can describe as the instrumentalization of the political within a religious institutional strategy of recognition. By corroborating government policy on religious institutions, the Bom Deus managed to position itself within the Angolan religious panorama. It grew from a foreign, Congolese church to a visible and recognized religious institution in Angola. Moreover, in one of the interviews for the local journal the church leader Simão Lutumba recently stated, "The Gospel was founded in this country and spread to other places', 8 thus showing the church's full insertion in the Angolan politico-religious landscape. By spreading the church to eighteen provinces of the country - following the INAR's (National Institute of Religious Affairs) two-thirds national territory coverage requirement for any church recognition - changing the language of the services from Lingala (a language with no official recognition in Angola) to Kikongo and Portuguese, and supporting obligatory pastor mobility through various parishes in different provinces of Angola, dismantling Bakongo dominance in the church structure, the Bom Deus grew hand in hand with political narratives on modern Angola, perceived as unified in its diversity yet with a clearly marked and delimited national identity (Schubert 2015). However, these structural changes that Bom Deus went through do not influence the church's spiritual dimension nor do they shape politically active subjects. In this sense, the engagement of the church in political issues is limited to concern for their own profits.

As the Angolan AG, the Bom Deus also contributes to the political program of molding new citizens who should follow Christian ethics, just as Angola is presented in political discourses as a traditionally Christian country. ${ }^{9}$ While this is happening in mainstream churches, several other religious groups are not yet legalized in the country. This is the case with the Muslim community, which despite its demographic relevance has yet to obtain recognition. This is another example of the political steering of the religious landscape in Angola (Blanes 2015b). Many churches are also used as channels to apply social programs on the ground such as those concerning basic health education or the control of specific social behaviors (e.g., alcohol consumption or sexual practices). In this sense these churches align with the country's political programs that are forged by the ruling elite. However, these activities do not create any evident interplay between the two realms of the religious and the political, and may instead be seen in terms of managerial talent in negotiating the limits of state impositions on their religious institutions. Before we ruminate on these (dis)connections in Angola's Pentecostalism and Evangelicalism, we introduce another case, approaching the 'revolutionary' problematic from a different angle. 


\section{On Making a Difference in Luanda}

In October 2016, Blanes was in Cacuaco, one of the northern districts of Luanda, to meet a few friends from the so-called 'Revú' (Revolutionary) Movement in Angola. ${ }^{10}$ Many of them were rappers belonging to an extreme hip hop crew known as the Terceira Divisão (Third Division) and grew up in the district, which they described as a 'stone in the shoe' (pedra no sapato) for the government, considering the older and more recent histories of protest against the regime. ${ }^{11}$ In regard to their religious or spiritual perspective, most of them were atheist, Rastafarian, or Muslim. It was thus somewhat of a surprise to learn that the purpose of the meeting was a culto evangélico, an evangelical service. The reason for this was interesting: the service was going to be held in honour of Dago Nível, a young activist from Cacuaco who had been sentenced to eight months in prison due to his outspoken criticism against the regime in the aftermath of another condemnation: that of the $15^{+2}$, accused of an attempted coup d'état of which some were residents in Cacuaco and members of the Terceira Divisão.

On that occasion Blanes learned that the service would be conducted by a pastor (name omitted here) who was a former member of the Terceira Divisão but later converted to Evangelicalism. Before the event the pastor confessed to Blanes that after his conversion to Christianity he had remained outside the political sphere (fora da política), but once he saw what was happening to his old neighbourhood friends he decided that he had to do something about it. The service was thus presented as a unique event, the first time a religious service was held in honour of the Revú cause in Angola.

It was indeed a unique and, in its early stages, awkward event. It began with several interventions from the members of the Terceira Divisão, who shared memories of how they met Dago as well as the pastor, interspersed with cries of 'Liberdade Já!' (Freedom Now!) from the audience. One of the speakers told those present that he had visited Dago in prison and observed that he 'sempre se manteve firme' (always remained positive) in jail. He continued his activism in prison, denouncing several human rights violations he witnessed such as several cases of excessive preventive imprisonment and the presence of minors (such as a twelve-year-old that was there at the time). Dago had heard about this initiative and expressed that he wanted to meet the pastor of this service because most Christian and Evangelical pastors he knew were 'parceiros da ditadura' (associates of the dictatorship). José Gomes Hata, one of the activists of the Terceira Divisão who is also one of the $15^{+2}$ and a Muslim, explained that 'if we usually criticize the churches for their apathy regarding 
problems in our society', we should support this initiative of doing what every church should do: claim justice.

The service started with a woman from the pastor's church singing praise songs and inviting those present to sing, praise the Lord, and clap their hands. Considering that many of those present were atheists, Rasta, or Muslim, one could sense the initial discomfort inside the warehouse where the service was taking place. With time, the environment became more relaxed and communal. Eventually, after a round of collecting offerings for Dago's family, the pastor began to speak. His sermon, Blanes eventually learned, was addressed to both the government of Angola and to the Christian pastors in Angola, whom he described as 'fearful' and 'cowardly'.

Today's theme will be the care of the Lord for prisoners. Hebrews 13: 3: 'Remember the prisoners as if you were imprisoned like them'. God makes no exception in people; he loves all. We must have concern, watch out for those who are incarcerated and are wronged. Life is very simple, but we complicate life. What is a prison? 'Prison' comes from arresting, capturing, putting in prison those who broke the law. It comes from Latin and means 'deprivation of liberty'. This applies to all walks of life.... We can also be imprisoned spiritually. He who arrests others is a spiritual prisoner, because he is in the right to arrest who he wants to.

In the penal code there are two prisons: the lightest prison and the most serious prison (seclusion). The lightest is applied to crimes of lesser gravity, which will have a reduced penalty. In Dago's case, for example, he did not deserve even detention for the crime he committed.... But unfortunately, in Angola in this way, prisons are degrading. But our people do not know how to argue; they accept everything.

In this first comment the pastor focused on the problem of punishment and incarceration, and how it incorporates a moral problem in terms of who has the legitimacy to apply justice and in what terms.

The question is: is the law being applied legitimately? How is it applied in our country? Has the legal system acted according to the laws? Or do they do it for your interests? Timothy 1: 8-10. 'But we know that the law is good, if any man uses it lawfully'. The laws are good, we cannot despise them, and they become better if they are used legitimately. 'The laws were not made for the righteous'; they are created for the unrighteous. 
Beloved ones, there is a serious problem with laws; laws are violated, and no one says anything. This country is a survival hole.... We need people to give themselves over, just as Jesus gave himself to the cross.... People need to know the law in order to better demand. Our God is the God of laws.... We are men, not ants.

The pastor went on to explain how the MPLA regime was using the law to control, manipulate, and intimidate the people as a strategy of self-preservation, where corruption (as in money for consent) was the most common strategy. ${ }^{12}$ He then explained the importance of activism against injustice through nonviolent resistance, claiming that the first one to do this was Jesus Christ, and urging unity to be strong in the struggle.

Dago was right in saying: this is a circus, and we know who the clowns are, they are identified. Being a good leader is being a fair man, so people will respect you. We do not need sycophants; each one must be firm in what he must do. The children of God must be righteous. But unfortunately, we are in a society where those who do not follow the jurisprudence are applauded.

He then moved from a diagnostic into a suggestion:

If each one did the right thing, including the church, we would not be in that situation. The church has no power, it only takes money from the people without conscience, and the pastors get rich. This is a sin, the truth must be told.... The church has an important role in society: activism. I came from hip hop and became a believer because of hip hop, the search for information. We started studying theology with Hata, and so I chose God. We need people who go to the rulers to say: "Thus says the Lord, this that you are doing is so bad!' But nobody does that. We know very well that pastors just get there, receive a lot of money, and start to claim that the president is God's chosen one.

The pastor saw the church (meaning Christian and notably Evangelical and Pentecostal churches) as being equally responsible for the moral breakdown in Angolan society and politics due to its own 'spiritual imprisonment'. Simultaneously, he advocated for an activist church. 'Prayer is the weapon', he would eventually claim. 
I thank the courage of the activists in Angola and in the world, I thank the good men who are everywhere, men of conviction. We are not defending a religion but speaking of men who demonstrate what is right and just. Events such as this one should have a greater impact.... We need a new people. When speaking of a New Angola, there is talk of an Angola with prostitutes. This is not the Angola we want!

These excerpts from the pastor's sermon are quite unique in the sense that they convey a form of immanent critique vis-à-vis the political role of Christian churches, using a multiple referentiality of sorts: they simultaneously issued a critique against the regime (understood in its wider sense) in Angola, a critique of Christian (and Pentecostal) leadership; and a praise of the 'activist' frame of mind, as the 'true Christian spirit', as it were. He exposed what Blanes calls the 'current state of anomie' in Angola (2019b), i.e., the perception of governmental failure (financial, cultural, political) as a 'moral breakdown' that replicates corrupt, selfish, tamed citizens. However, he did not just locate the source of the moral breakdown within the government, but also within the churches that were compliant, silent enablers. This reveals the particular space of intersection between church and state in Angola, characterized at the same time by the idea of approximation to statehood that is a prostitution (because it only produces rich pastors), and the idea of self-exclusion on the part of the churches, from the space of the political, which is cowardly and ultimately equally guilty in the moral breakdown. ${ }^{13}$ The pastor's solution - one that has to be understood as marginal and antihegemonic within the Angolan religious landscape - was thus an activist church, one that resists corruption, fights injustice and inequality, interprets the Bible as a source of law, and intervenes in the public space for a righteous political governance.

\section{Political Engagement for Antirevolution}

All three examples of the AG Maculusso retreat, the Bom Deus reconversion into Angolan modernity, and the nonaligned Pentecostal pastor in Cacuaco, however divergent, illustrate two things: while they acknowledge a political role of the Christian church in the Angolan nation, they expose a more abstract configuration of the political, one that appeals to a moral dimension that in any case remains separated from the realm of concrete politics (parties, politicians, political strategies, etc.). In this respect, while the country was experiencing increasing financial and political strife, the Pentecostal and Evangelical leadership was either engaging in paternalistic and abstract moral 
discourses (ritual events of caring for the nation) or in strategies for self-profit. This paternalistic moral stance toward the political ultimately exposes a conservative and at the same time contradictory configuration: while exposing the urgency of a moral reform in Angola, they choose the status quo.

The ambiguous perception of the revolution according to the Pentecostal and Evangelical circuits in Angola, as depicted in this article, builds on the political theology that excludes certain notions of political and political engagement from the Christian sphere of interest and actions. Observed as a system (Schubert 2017), for Angola's Evangelicals and Pentecostals the political appears as an external reality, existing outside the religious realm. This division resembles the biblical statement to 'render to Caesar the things that are Caesar's, and to God the things that are God's' (Matthew 22: 21) - or, as is typically said in Angola, 'cada macaco no seu galho' (each monkey in its own branch) - and as such entails the definition of politics and political agency to be constructed in a parallel manner in different spheres. As a result, the different ontologies of the two realms, religious and secular, easily lead to instrumentalizations processed in dual directionality, but without any significant interconnections and engagement between them.

This is illustrated in the cases of Bom Deus and Luz do Mundo churches described in this article. Angolan Pentecostals in Portugal and Great Britain frequently transmitted to Zawiejska the divergent character of the two realms in the wake of the Revús case. Her main interrogation of religious leaders and church members was about the role of the church in respect to unjust yet 'legitimate' government. The initial responses she received pointed to the impossibility of any political engagement due to her interlocutors' oppressive and hegemonic perception of Angola's political power. These convictions were transmitted from the position of Angolan citizens who commented on the current political situation in their country.

However, the notion of agency radically changed upon entering the religious realm. Several conversations during Zawiejska's fieldwork referred to the biblical figures of David and Goliath as an example of the solution to Angola's political issues. As in the case of the AG Maculusso retreat described above, the source of agency was placed in religious practice and trust in God. A similar strategy is highlighted by David Garbin and Marie Godin in relation to the case of the Congolese 'pasteurs combatants', Pentecostal religious leaders in the Congolese diaspora who take critical stances regarding Congolese politics while claiming that real agency may be achieved through the battle ongoing at the spiritual level (2013). The divergent perceptions of the political, according to different ontological realms in Angolan Pentecostal and Evangelical churches, vividly shape the internal religious revolutionary narrative. 
In Angola the Pentecostal revolution, as understood by religious institutions, takes the form of an inward social change, based on the conviction of creating Christian subjects of the Christian nation, as Angola's political leaders normally perceive the country. Such revolution is inscribed in a rather long process and will require an explosive nature of significant sociopolitical engagement. However, it is worth discussing to what extent it might resemble what Devaka Premawardhana observes in the case of the Pentecostal presence in Niassa region of Northern Mozambique, where Pentecostal conversions are followed by fluidity of identity negotiations and thus engage in constant rethinking of social experiences and reshaping of social activities (2018). Such change, as Zawiejska observed in relation to the activity of AG women's associations in Luanda, could be approached in terms of performative practices that are linked to religious rituals. As Zawiejska noted, the circulation of AG women through different spatialities in Luanda is often interpreted by the women themselves as reworking ethnic divisions, practicing social inclusiveness, and reimagining stigmatized spaces in contemporary Luanda. Women's prayer meetings, as that in AG Maculusso depicted above, may be read in this case, as Covington-Ward suggests, through religiously acting bodies in relation to certain political claims (2016). Covington-Ward's 'performative encounters' are informed by the idea that the strategic use of bodies, in this case the urban circulation of women's associations together with common prayer meetings, impacts social and political positioning of interacting people. From this perspective, several Pentecostal practices in Angola may be read as political initiatives.

Nevertheless, in the Angolan context such changes appear as a process separated from activism or political intervention, and may eventually take place within the secular realm if it is religiously mediated. In this sense, the revolutionary component of the Pentecostal and Evangelical movement vis-à-vis the public sphere, as portrayed in the social sciences, may be understood, as the Angolan example shows, as an unfolding of an intrinsic religious narrative with little to no effect in partisan politics, and ultimately an invitation to withdraw from oppositional politics. To take on a suggestive title of Matthews Ojo (2007), while Evangelicals and Pentecostals engage in the mobilization of 'endtime armies', such armies are not geared to fight external political opponents, but instead the enemies within.

What, then, does the Angolan case tell us in terms of understanding religion and politics in Africa today, in particular in a historical moment in which many 
countries in this continent have or are about to celebrate fifty years of independence and experience new waves of political opposition and activism? From our standpoint, Evangelical and Pentecostal politics involves a strategy of co-optation into elite citizenship, a defense of the political status quo, and/ or an explicit withdrawal from concrete political warfare.

In this framework, it is not our intention to produce an overarching continental argument concerning Evangelical and Pentecostal tactics of selfexclusion, but rather to decouple the narrative of Pentecostal revolution from an empirical movement, in particular in what determines the engagement with partisan politics. Ruth Marshall's invocation of Pastor Ojewale's speech in her book Political Spiritualities (2009) is, we believe, telling:

This is the eve of a national revival. Call it spiritual awakening or revolution if you please. There are few revolutions in history without bloodshed. But there is one revolutionary - the greatest revolutionary of all time - who did not shed another's blood to establish his Kingdom.... His was a spiritual revolution and it has changed the course of the history of man. $(2009,1)$

\section{Acknowledgement}

This article is made open access with funding support from the Jagiellonian University under the Excellence Initiative - Research University programme (the Priority Research Area Heritage).

\section{References}

Agamben, Giorgio. 2012. The Church and the Kingdom. London: Seagull Press.

Biehl, João. 2014. Vita. Life in a Zone of Social Abandonment. Berkeley: University of California Press.

Blanes, Ruy Llera. 2014. A Prophetic Trajectory: Ideologies of Place, Time and Belonging in an Angolan Religious Movement. Oxford \& New York: Berghahn Books.

Blanes, Ruy Llera. 2015a. 'The Angolan Apocalypse. Prophecies, Imaginaries and Political Contestations in Post-War Angola'. Social Sciences and Missions 28.3-4, 217-234.

Blanes, Ruy Llera. 2015b. 'Politics of Sovereignty: Evangelical and Pentecostal Christianity and Politics in Angola'. In Simon Coleman and Rosalind Hackett (eds.), The Anthropology of Global Pentecostalism and Evangelicalism. New York: New York University Press, 197-213. 
Blanes, Ruy Llera. 2015c. 'Revolutionary States in Luanda: Events and Political Strife in Angola'. Focaal Blog.

Blanes, Ruy Llera. 2017. 'A Febre do Arquivo. O Efeito Benjamin e as Revoluções Angolanas'. Práticas da História 3, 71-92.

Blanes, Ruy Llera. 2019a. 'Austerity en Route, from Lisbon to Luanda'. Focaal 83.1, 37-5o.

Blanes, Ruy Llera. 2019b. 'The Current State of Anomie in Angola'. Durkheimian Studies 23.1, 26-39.

Blanes, Ruy, and Abel Paxe. 2015. 'Atheist Political Cultures in Independent Angola'. Social Analysis 59.2, 62-80.

Burgess, Richard. 2015. 'Pentecostals and Politics in Nigeria and Zambia. A Historical Perspective'. In Martin Lindhardt (ed.), Pentecostalism in Africa. Presence and Impact of Pneumatic Christianity in Postcolonial Societies. Leiden: Brill, 291-321.

Chesnut, Andrew. 1997. Born Again in Brazil. The Pentecostal Boom and the Pathogens of Poverty. New Brunswick, NJ: Rutgers University Press.

Comaroff, Jean. 2009. 'The Politics of Conviction. Faith on the Neo-Liberal Frontier'. Social Analysis 53.1, 17-38.

Comaroff, Jean, and John Comaroff. 1991. Of Revelation and Revolution, Volume One. Christianity, Colonialism, and Consciousness in South Africa. Chicago, IL: University of Chicago Press.

Covington-Ward, Yolanda. 2016. Gesture and Power. Religion, Nationalism and Everyday Performance in Congo. Durham, NC: Duke University Press.

Cox, Harvey. 1995. Fire from Heaven. The Rise of Pentecostal Spirituality and the Reshaping of Religion in the Twenty-First Century. New York: Da Capo Press.

Englund, Harri. 2007. 'Pentecostalism Beyond Belief: Trust and Democracy in a Malawian Township'. Africa 77.4, 477-499.

Fernando, Manuel. 2010. As Religiões em Angola. A Realidade do Período PósIndependência (1975-2010). Luanda: INAR.

Fischer, Moritz. 2011. Pfingstbewegung zwischen Fragilität und Empowerment. Beobachtungen zur Pfingstkirche „Nzambe Malamu“ mit ihren transnationalen Verflechtungen. Frankfurt: VR Unipress.

Freeman, Dena (ed.). 2012. Pentecostalism and Development. Churches, NGOs and Social Change in Africa. Hampshire: Palgrave Macmillan.

Freston, Paul. 2001. Evangelicals and Politics in Asia, Africa and Latin America. Cambridge: Cambridge University Press.

Garbin, David, and Marie Godin. 2013. "Saving the Congo": Transnational Social Fields and Politics of Home in the Congolese Diaspora'. African and Black Diaspora: An International Journal 6.2, 113-130.

Gifford, Paul. 1995. Christian Churches and the Democratisation of Africa. Leiden: Brill. Gifford, Paul. 1998. African Christianity. Its Public Role. London: Hurst. 
Harding, Susan. 200o. The Book of Jerry Falwell: Fundamentalist Language and Politics. Princeton, NJ: Princeton University Press.

Hastings, Adrian. 1995. 'The Churches and Democracy: Reviewing a Relationship'. In Paul Gifford (ed.), The Christian Churches and the Democratisation of Africa. Leiden: Brill, 36-46.

Haynes, Naomi. 2015. 'Zambia Shall be Saved! Prosperity Gospel Politics in a Self-Proclaimed Christian Nation'. Nova Religio 19.1, 5-24.

Haynes, Naomi. 2018. 'Why Can't a Pastor Be President of a "Christian Nation"? Pentecostal Politics as Religious Mediation'. PoLAR: Political and Legal Anthropology Review 41.1, 6-74.

Lindhardt, Martin (ed.). 2015. Pentecostalism in Africa. Presence and Impact of Pneumatic Christianity in Postcolonial Societies. Leiden: Brill.

Mafra, Clara. 2002. Na Posse da Palavra. Religião, Conversão e Liberdade Pessoal em Dois Contextos Nacionais. Lisbon: Imprensa de Ciências Sociais.

Mafra, Clara. 2003. 'A Sedução em Tempos de Abundância: Análise dos Templos Pentecostais como Objectos de Arte'. In Otávio Velho (ed.), Circuitos Infinitos: Comparações e Religiões no Brasil, Argentina, Portugal, França e Grã-Bretanha. São Paulo: Attar Editorial, 97-126.

Mafra, Clara, Claudia Swatowiski, and Camila Sampaio. 2012. 'O Projeto Pastoral de Edir Macedo. Uma Igreja Benevolente para Indivíduos Ambiciosos'. RBCs 27.78, 81-192.

Marshall, Ruth. 2009. Political Spiritualities. The Pentecostal Revolution in Nigeria. Chicago, IL: University of Chicago Press.

Martin, David. 1990. Tongues of Fire: The Explosion of Pentecostalism in Latin America. Oxford: Blackwell.

Martin, David. 1996. Forbidden Revolutions: Pentecostalism in Latin America and Catholicism in Eastern Europe. London: SPCK.

Martin, David. 2014. 'Nationalism and Religion, Collective Identity and Choice: The 1989 revolutions, Evangelical Revolution in the Global South, revolution in the Arab World'. Nations and Nationalism 20.1, 1-17.

Martins, José Manuel. 2004. Recantos do Mundo. O pentecostalismo em Angola subsídios para a história das Assembleias de Deus. Camarate: SIG.

McCauley, John. 2015. 'Pentecostals and Politics. Redefining Big Man Rule in Africa'. In Martin Lindhardt (ed.), Pentecostalism in Africa. Presence and Impact of Pneumatic Christianity in Postcolonial Societies. Leiden: Brill, 322-344.

Meyer, Birgit. 1998. 'Make a Complete Break with the Past: Memory and Post-Colonial Modernity in Ghanaian Pentecostalist Discourse'. Journal of Religion in Africa 28.3, 316-349.

Miranda, Jorge. 2010. 'A Constituição de Angola 2010'. Systemas - Revista de Ciências Jurídicas e Econômicas 2.1, 119-146. 
Morier-Genoud, Éric. 2014. 'Renouveau religieux et politique au Mozambique: Entre permanence, rupture et historicité.' Politique Africaine 134.2, 155-177.

Muekalia, Jardo. 2017. Angola, A Segunda Revolução. Memórias da Luta Pela Democracia. Porto: Sextante.

Neves, Tony. 2012. Angola. Justiça e Paz nas Intervenções da Igreja Católica, 1989-2002. Lisbon: Texto Editores.

Ojo, Matthews. 2007. The End-Time Army: Charismatic Movements in Modern Nigeria. Trenton, NJ: Africa World Press.

O’Neill, Kevin. 2010. City of God. Christian Citizenship in Postwar Guatemala. Berkeley: University of California Press.

Orre, Aslak. 2015. 'Covering Up a Massacre in Angola?' Post @ Christian Michelsen Institute.

Pearce, Justin. 2015. Political Identity and Conflict in Central Angola, 1975-2002. Cambridge: Cambridge University Press.

Péclard, Didier. 2013. 'The "Depoliticizing Machine". Church and State in Angola Since Independence'. In Paul C. Manuel, Alynna Lyon, and Claude Wilcox (eds.), Religion and Politics in a Global Society: Comparative Perspectives from the Portuguese-speaking World. Lanham, MD, 139-16o.

Prandi, Reginaldo, and Renan W. Dos Santos. 2017. 'Quem tem medo da bancada evangélica? Posições sobre moralidade e política no eleitorado brasileiro, no Congresso Nacional e na Frente Parlamentar Evangélica'. Tempo Social 29.2, 187-213. Premawardhana, Devaka. 2018. Faith in Flux. Pentecostalism and Mobility in Rural Mozambique. Philadelphia: University of Pennsylvania Press.

Ranger, Terence (ed.). 2008. Evangelical Christianity and Democracy in Africa. Oxford: Oxford University Press.

Rocha, Edmundo. 2003. Contribuição ao Estudo da Génese do Nacionalismo Moderno Angolano: período de 1950-1964: testemunho e estudo documental. Luanda: Kilombelombe.

Sanneh, Lamin, and John Carpenter (eds.). 2005. The Changing Face of Christianity. Africa, the West, and the World. Oxford: Oxford University Press.

Sarró, Ramon. 2018. 'Religious Pluralism and the Limits of Ecumenism in Mbanza Kongo, Angola'. Journal of Southern African Studies 44.2, 239-251.

Schubert, Benedict. 1999. 'Os Protestantes na Guerra Angolana depois da Independência'. Lusotopie 6: 405-413.

Schubert, Benedict. 2000. A Guerra e as Igrejas. Angola 1961-1991. Basel: P. Shlettwein Publishing.

Schubert, Jon. 2015. '2002, Year Zero: History as Anti-Politics in the "New Angola". Journal of Southern African Studies 41 (4): 835-852.

Schubert, Jon. 2016. 'Emerging Middle-class Political Subjectivities in Post-war Angola'. In Henning Melber (ed.). The Rise of Africa's Middle Class. London: Zed Books, $147^{-158 .}$ 
Schubert, Jon. 2017. Working the System. A Political Ethnography of the New Angola. Ithaca, NY: Cornell University Press.

Viegas, Fátima. 2007. Panorama das Religiões em Angola. Dados Estatísticos 2007. Luanda: Instituto Nacional para os Assuntos Religiosos.

Zawiejska, Natalia. 2016. 'Angolscy chrześcijanie w Portugalii: Procesy konstrukcji tożsamości wspólnot ewangelikalnych w warunkach migracji'. PhD thesis, Uniwersytet Jagielloński, Cracow.

Zawiejska, Natalia. 2017. 'O Templo Central da Igreja do Bom Deus'. In Ruy Blanes and Ramon Sarró (eds.), Paisagens e Memórias Religiosas em Angola: Um Itinerário, volume 1. Lisbon: Currents of Faith, Places of History, $5^{0-56 .}$

Zawiejska, Natalia. 2020. 'Angola'. In Michael Wilkinson, Connie Au, Jörg Haustein, and Todd M. Johnson (eds.), Brill's Encyclopedia of Global Pentecostalism. http://dx.doi .org/10.1163/2589-3807_EGPO_COM_034822.

Zawiejska, Natalia, and Linda van de Kamp. 2018. 'The Multi-Polarity of Angolan Pentecostalism: Connections and Belongings'. PentecoStudies 17.1, 12-36.

\section{Notes}

1 We are aware of the empirical complexity and heterogeneity that is encapsulated under an umbrella term such as 'Evangelical and Pentecostal movements'. We use as a framework for this matter churches that focus on the experience and agency of the Holy Spirit, and highlight the importance of charismatic gifts in both individual and collective ritual terms.

2 Here we are referring to the long-lasting civil war that marked the first thirty years of Angolan independence (1975-2002), and to the recognized contribution of mainstream churches in the multiple instances of peace-building policies in Angola. In particular, in 1990-1992 we refer to the framework of the failed peace accords of Bicesse, and in 2002 after the armistice that put an end to the war (see, e.g., Neves 2012).

3 See Angola Press, 1 October 2014. 'Kundi Paihama insta fiéis da seita Kalupeteka a respeitarem ordem social'. Retrieved on 14 September 2017.

OFPrA, 10 November 2016, 'L'Eglise Évangélique Sétimo Dia a Luz do Mundo et son leader José Julino Kalupeteka'. Accessed 30 July 2020.

United States of America Government, 2015 ‘ Angola 2015 International Religious Freedom Report', Retrieved on 29 July 2020.

United States of America Government, 2016. 'Angola 2016 International Religious Freedom Report', Retrieved on 29 July 2020.

4 In July 2020 a conflict arose in the IURD in Angola. Local pastors accused the Brazilian hierarchy of mistreatment, abuse of authority, and unfair treatment in regard to the promotion of ministers. Other voices soon joined the critics, noting the lack of sustainment in the church's social campaigns and self-transformation work. Several critics targeted the church doctrine, evaluating it as based on a short-lived delight due to the church's luxurious style and the promise of immediate fulfillment. Along with these controversies, an older issue was brought into the discussion regarding the church's 'foreign' condition, frequently played by the government authorities in relation to various religious groups. Since most religious institutions in Angola are the outcome of foreign missions, upon establishment in the country they become 'nationalized' (Péclard 2013), as for instance the Assemblies of God of Angola who 
went through a process of 'Africanization'. In the case of IURD, the perceptible foreignness is reported at all levels of church life, observable in ritual style, the pastors' accent, and the hierarchy in management. While so far the state has remained neutral regarding the conflict, it is suspected that there is an overarching interest in the ultimate nationalization of the church.

5 Its full name is Igreja Fraternidade Evangélica de Pentecostes na África em Angola Bom Deus, IFEPÁA - Bom Deus (Evangelical Brotherhood of Pentecostals in Africa in Angola - Good God Church).

6 The Angolan Assembly of God (AG) integrates several autonomous assemblies united under a common leadership. Among the most significant assemblies are AG Maculusso, AG Ebenezer, AG Salém, AG Terra Nova, and AG Nova Aliança. After the passing of Rev. Fernando Manuel Panzo (2017), the leader of AG Ebenezer and the main leader of Angolan God Assemblies, the leadership was entrusted to the main pastor of AG Maculusso, Rev. Francisco Domingos Sebastião. This has enhanced the leading position of AG Maculusso in the AG landscape in Angola.

7 This observation was made at a moment in which Angola was already experiencing a major financial crisis (Blanes 2019a).

8 Correiro da Kianda, 19 February 2019. 'Igreja Bom Deus inaugura Templo internacional em Luanda'. Retrieved on 4 July 2020.

9 However, not all Angolans adhere to Christianity. Approximately 41 percent of the population is Roman Catholic and 38 percent are Protestant, according to the 2014 Census of the National Institute of Statistics (INE) in Angola.

10 'Revú' is an abbreviation of the name Movimento Revolucionário (Revolutionary Movement), an umbrella term that refers to several activist movements that emerged in Angola in 2011 in the aftermath of the Arab Spring. Largely situated beyond partisan politics, such movements include artists, musicians, lawyers, teachers, and students. These movements staged several demonstrations over the past years that invariably ended in violent confrontations with the police and army forces. In 2015 one such group of activists was arrested and accused of an attempted coup d'état for discussing strategies to combat the regime's dictatorship. This case became known as the ' $15+2$ ' process (see Blanes $2015 \mathrm{c}$, 2017, 2019a).

11 Cacuaco is often described as a stronghold of the UNITA, the main opposition party.

12 There has been a long debate in Angola concerning the last constitutional revisions (in particular that of 2010) and the rule of law, seen as constructed to benefit a party and its president instead of the people (See, e.g., Miranda 2010).

13 As another illustration of this process, in November 2016 the CICA was accused of playing the government's game when they agreed to organize a march and demonstration in the $1^{\circ}$ de Maio square in Luanda under the motto 'The Role of the Religious Woman in the Consolidation of Peace in Angola'. This was scheduled on precisely the same date (26 November) and location where another demonstration organized by several activist and civil society groups was going to take place protesting the nomination of the then president's CEO of the main oil company (Sonangol). See, e.g., Voice of America, 29 November 2016, 'Conselho de Igrejas Cristãs de Angola refuta ter sido manipulado pelo Governo'. Retrieved on 20 May 2017. 